\title{
PELATIHAN PEMBUATAN BODY CREAM DAN LOTION LIDAH BUAYA (ALOE VERA) DI PURI DAMAI DESA SINGAKERTA KECAMATAN UBUD KABUPATEN GIANYAR BALI
}

\author{
N.L. Arpiwi ${ }^{1}$, I.K.Muksin ${ }^{2}$, I.G.A.S. Wahyuni ${ }^{3}$, I.K.Ginantra ${ }^{4}$, N.W. Sudatri ${ }^{5}$
}

\begin{abstract}
ABSTRAK
Lidah buaya (Aloe vera) adalah tanaman sukulen dari keluarga Asphodelaceae yang tersebar luas di daerah tropis dan sub-tropis. Tanaman ini sangat populer karena memiliki banyak kegunaan, misalnya sebagai pelembab kulit, pertumbuhan rambut, dan pengendalian jerawat. Tujuan dari pelatihan ini adalah untuk memberikan informasi kepada masyarakat Desa Singakaerta, Kabupaten Gianyar, tentang bagaimana mengolah lidah buaya menjadi body cream dan lotion sehingga dapat meningkatkan nilai ekonomi tanaman tersebut. Prosedur kerja dimulai dengan mengupas daun lidah buaya untuk mendapatkan pulp, lalu diblender dan disaring untuk mendapatkan jus. Basis cream dan lotion terdiri dari minyak kelapa murni (VCO), cethyl alcohol, asam stearat, gliserin, triethanolamine, nipagin, nipasol dan aquades dengan jumlah sesuai formulasi. Fase air dicampur dengan fase minyak pada suhu $70^{\circ} \mathrm{C}$ sambil diaduk sampai homogen dan kemudian ditambahkan jus lidah buaya pada suhu $40^{\circ} \mathrm{C}$. Aroma cendana ditambahkan untuk body creamdan aroma melati ditambahkan ke body lotion pada suhu $30^{\circ} \mathrm{C}$. Body cream berwarna putih susu, aroma cendana, tekstur lembut, agak kental, $\mathrm{pH}$ 6,5, homogen dengan viskositas 95 poise. Body lotion berwarna putih susu, aroma melati, tekstur lembut, lebih encer, pH 7, homogen dengan viskositas 39 poise.
\end{abstract}

Kata kunci : Body cream, body lotion, Aloe vera, VCO

\section{PENDAHULUAN}

Desa Singakerta terletak di wilayah kecamatan Ubud, Kabupaten Gianyar Bali, yang terdiri dari 14 banjar atau dusun. Topografi Desa Singakerta adalah datar dengan jenis tanah ergosol dengan struktur lempung berliat dengan luas wilayah 312,52 hektar yang sebagian besar dimanfaatkan untuk lahan pertanian dengan jumlah penduduk 9,677 jiwa di tahun 2014 dengan kepadatan 1,395 jiwa/ $/ \mathrm{km}^{2}$.

Khalayak sasaran program Udayana Mengabdi 2019 adalah masyarakat banjar Tunon, Desa Singakerta, Kecamatan Ubud, Kabupaten Gianyar dengan mata pencaharian utama sebagai petani dan pengerajin patung. Komoditas yang ditanam adalah padi, palawija, sayur - mayur dan buah buahan. Keberadaan Puri Damai di Banjar Tunon merupakan sarana pengenalan tanaman obat obatan berdasarkan lontar Taru Premana. Selain itu juga merupakan sarana budidaya tanaman obat dari berbagai species termasuk lidah buaya yang sudah sangat terkenal khasiatnya.

\footnotetext{
${ }^{1}$ Dosen Program Studi Biologi Fakultas MIPA Universitas Udayana, Kampus Bukit Jimbaran, Badung, Bali. Email:arpiwi@unud.ac.id

${ }^{2}$ Dosen Program Studi Biologi Fakultas MIPA Universitas Udayana, Kampus Bukit Jimbaran, Badung, Bali.

${ }^{3}$ Dosen Program Studi Biologi Fakultas MIPA Universitas Udayana, Kampus Bukit Jimbaran, Badung, Bali.

${ }^{4}$ Dosen Program Studi Biologi Fakultas MIPA Universitas Udayana, Kampus Bukit Jimbaran, Badung, Bali.

${ }^{5}$ Dosen Program Studi Biologi Fakultas MIPA Universitas Udayana, Kampus Bukit Jimbaran, Badung, Bali.
} 
Pembuatan obat - obatan tradisional berbasis herbal dan pemanfaaatanya telah diperkenalkan oleh pemilik Yayasan Puri Damai kepada masyarakat sekitar maupun yang datang dari berbagai penjuru melalui praktek usada. Kesadaran masyarakat untuk memanfaatkan herbal sebagai obat maupun perawatan tubuh sudah semakin meningkat dengan kemajuan teknologi informasi. Obat - obatan kimia serta produk bodycare yang banyak memanfaatkan bahan kimia banyak menimbulkan efek samping yang berbahaya bagi kesehatan untuk penggunaan jangka panjang.

Lidah buaya telah banyak dimanfaatkan dalam bidang industri kosmetik dan farmasi. Produk kosmetik yang berbahan dasar lidah buaya misalnya sabun, sampho, kondisioner, gel, hand body lotion, hair tonik, masker, lulur, toner, pembersih wajah dan penyegar. Produk farmasi berbahan lidah buaya misalnya minuman kesehatan. Daun lidah buaya yang terdiri dari kulit, eksudat dan pulp dapat dideversifikasi menjadi produk olahan berupa gel dan tepung lidah buaya. Pengolahan lidah buaya menjadi aneka produk dapat meningktakan nilai ekonominya (Hendrawati dkk, 2017).

Yayasan Puri Damai Banjar Tunon Desa Singakerta memiliki koleksi lebih dari 200 jenis tumbuhan baik sebagai tanaman obat maupun sarana upacara Hindu di Bali (Rusmarini dan Damai 2017). Lidah buaya adalah salah satu koleksi yang banyak digunakan sebagai pengobatan untuk luka bakar, tersiram air panas ringan, bisul, batuk, dan radang. Selain itu untuk perawatan tubuh lidah buaya banyak digunakan untuk menyuburkan rambut, masker penghalus dan pelembab kulit wajah, serta mendinginkan kulit yang terpapar sinar matahari. Daun lidah buaya mengandung metabolit skunder berupa saponin, tannin, flavonoid dan antrakuinon yang berfungsi sebagai anti septik dan anti oksidan (Kumar et al., 2012). Khasiat lidah buaya tersebut sudah disadari oleh masyarakat banajar Tunon, Desa Singakerta tetapi hanya sebatas penggunaan lidah buaya segar secara langsung dan belum dioleh menjadi produk.

Pembuatan produk berbasis daun lidah buaya menjadi body cream dan lotion untuk merawat kecantikan kulit sangat penting untuk meningkatkan nilai ekonomi tanaman tersebut. Dengan adanya Kelompok Wanita Kepala Keluarga (Pekka) dan Kelompok Turus Lumbung Puri Damai sebagai khalayak sasaran program pengabdian ini maka diharapkan program akan sukses dan berkesinambungan. Kelompok - kelompok ini perlu dilatih dan ditingkatkan keterampilanya dalam mengolah daun lidah buaya menjadi produk herbal bermanfaat yang nantinya bisa dipasarkan melalui koperasi unit desa setempat. Hal ini akan meningkatkan pendapatan mereka. Konsentrasi ekstrak lidah buaya pada produk body cream dan lotion diteliti dan sifat fisik produk diuji.

\section{METODE PELAKSANAAN}

\section{Tempat Pelaksanaan Pelatihan}

Pelaksanaan kegiatan Program Udayana Mengabdi bertempat di Puri Damai yang terletak di Banjar Tunon, Desa Singakerta, Kecamatan Ubud Kabupaten Gianyar. Alasan pemilihan tempat tersebut karena Puri Damai memiliki ruangan pertemuan yang dilengkapi fasilitas tempat duduk dan ruang terbuka yang bisa menampung 50 orang sehingga kegiatan akan bisa berlangsung dengan baik. Fasilitas lain yang ada di Puri Damai adalah kebun koleksi tumbuhan obat dan sarana upakara Hindu yang terdiri dari lebih 200 species (Rusmarini dan Damai 2013). Para peserta pelatihan bisa mengamati secara langsung cara budidaya tumbuhan obat khususnya lidah buaya yang nantinya dipakai bahan pelatihan. Pengetahuan budidaya juga sangat penting untuk pengembangan tanaman lidah buaya jika nantinya para khalayak sasaran membuka usaha pertanian lidah buaya. Bahan baku yang dihasilkan sendiri akan mempermudah proses produksi, karena selalu tersedia, tidak perlu biaya transportasi dan tersedia setiap saat.

\section{Metode Pelaksanaan Kegiatan}


Metode pelaksanaan kegiatan Program Udayana Mengabdi diawali dengan sosialilasi kegiatan kepada kelompok khalayak sasaran yang akan dilibatkan di Puri Damai. Sosialisasi sangat penting selain menyebarkan informasi kegiatan juga mendengarkan masukan - masukan dari khalayak sasaran sehingga kegiatan yang akan dilaksanakan bisa memberi manfaat maksimal dan sesuai kebutuhan khalayak sasaran.

Pelaksanan kegiatan dirundingkan antara pihak pelaksana dari Universitas dengan khalayak sasaran sehingga mendapatkan waktu yang tepat yang tidak berbenturan dengan kegiatan masyarakat lainnya. Pelaksanaan pelatihan diawali dengan penjelasan prosedur kerja sebagai berikut:

Pembuatan body cream mengikuti metode Syamsiah dkk (2016) dan Usman (2018) dengan modifikasi. Formulasi body cream dan body lotion untuk membuat $3000 \mathrm{~mL}$ adalah seperti pada tabel 1 di bawah ini.

Tabel 1. Komposisi body cream dan body lotion lidah buaya

\begin{tabular}{lcc}
\hline Bahan & Body cream $(\mathrm{g})$ & Body lotion $(\mathrm{g})$ \\
\hline VCO & $300 \mathrm{~g}$ & $300 \mathrm{~g}$ \\
Setil alkohol & $120 \mathrm{~g}$ & $60 \mathrm{~g}$ \\
Asam stearat & $150 \mathrm{~g}$ & $90 \mathrm{~g}$ \\
Gliserin & $150 \mathrm{~g}$ & $300 \mathrm{~g}$ \\
Trietalonamin & $36 \mathrm{~g}$ & $36 \mathrm{~g}$ \\
EDTA & $60 \mathrm{~g}$ & $60 \mathrm{~g}$ \\
Nipagin & $3 \mathrm{~g}$ & $3 \mathrm{~g}$ \\
Nipasol & $3 \mathrm{~g}$ & $3 \mathrm{~g}$ \\
Jus lidah buaya & $300 \mathrm{~mL}$ & $600 \mathrm{~mL}$ \\
Aquades & $3000 \mathrm{~mL}$ & $3000 \mathrm{~mL}$ \\
Pewangi & & \\
cendana & $20 \mathrm{~mL}$ & $20 \mathrm{~mL}$ \\
\hline
\end{tabular}

Daun lidah buaya dipetik kemudian dibiarkan pada suhu ruang untuk menghilangkan getahnya. Kulit daun lidah buaya dikupas untuk mendapatkan pulp, kemudian dikukus selama 15 menit, diblender dan disaring sehingga diperoleh jus lidah buaya. Penjelasan tentang bahan - bahan yang digunakan dalam pembuatan body cream dan body lotion dilakukan dengan memperlihatkan bahan - bahan satu per satu kepada para peserta pelatihan. Kegunaan masing - masing bahan juga dijelaskan sehingga para peserta mendapatkan pemahaman.

Proses pembuatan body cream dan lotion (Gambar 1) diawali dengan pemanasan fase minyak dan fase air dalam wadah terpisah. Fase minyak yang terdiri dari Virgin Coconut Oil (VCO) asam stearat, nipasol dan setil alkohol dipanaskan dengan hot plate menggunakan gelas beker terpisah, setelah bahan - bahan tersebut meleleh kemudian dicampurkan menjadi satu sambil diaduk. Fase air yang terdiri dari aquades, Trietanolamin, EDTA, nipagin, dan jus lidah buaya kemudian dipanaskan pada suhu $70^{\circ} \mathrm{C}$ sambil diaduk hingga tercampur merata. Pada suhu $70^{\circ} \mathrm{C}$, fase minyak dicampurkan dengan fase air secara perlahan - lahan sambil dimixer sehingga diperoleh body cream yang homogen. Body cream didinginkan pada suhu ruang, kemudian ditambahkan dengan pewangi cendana sambil diaduk hingga tercampur merata, sedangkan body lotion ditambahkan pewangi melati. 

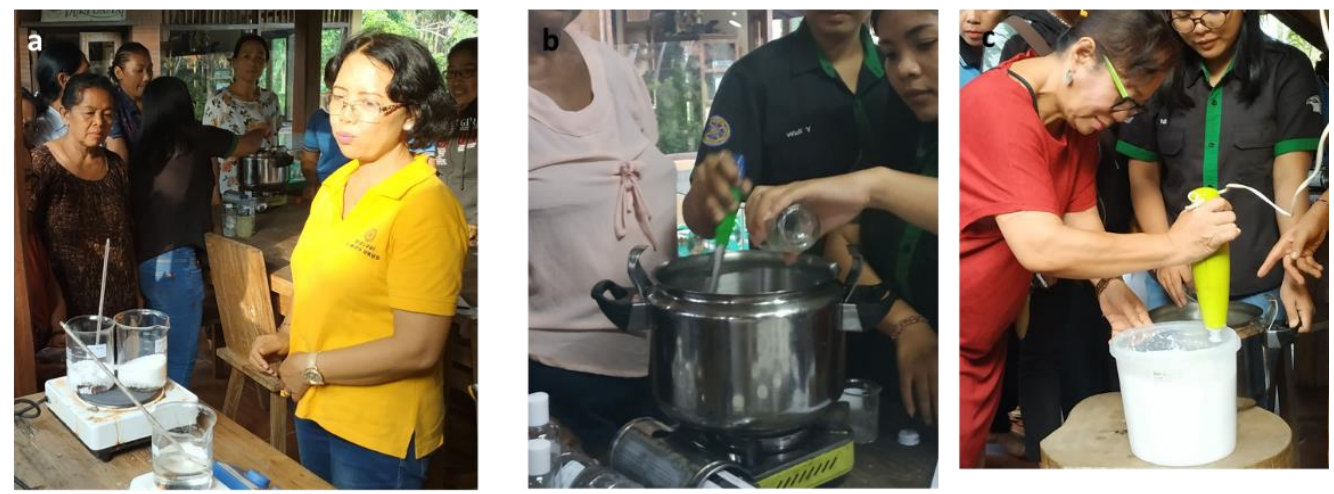

Gambar 1. Proses pembuatan body cream dan body lotion lidah buaya. a) pemanasan fase minyak, b) pemanasan dan pencampuran fase air pada suhu $70^{\circ} \mathrm{C}, \mathrm{c}$ ) pencampuran fase minyak dan fase air dengan dimixer.

Produk yang dihasilkan dari pelatihan berupa body cream dan body lotion lidah buaya diuji kualitasnya secara organoleptik, meliputi bau, warna, tekstur dan kesan. Untuk pengujian kesan dilakukan dengan mencoba mengoles pada lengan peserta pelatihan serta mengamati proses absorbsi produk pada kulit serta rasa yang diperoleh pada kulit, apakah segar dan lembut.

Body cream lidah buaya dikemas dalam jar plastik dengan volume $100 \mathrm{~mL}$ sedangkan lotion lidah buaya dikemas dalam botol plastik $100 \mathrm{~mL}$ yang telah diberi label. Label diberi logo, nama produk, komposisi bahan dan cara pakai.

Pendampingan dilakukan selama pelatihan berlangsung supaya peserta benar - benar mengerti dan mampu mebuat cream dan lotion lidah buaya sendiri. Monitoring ke Puri Dami dan kelompok kelompok khayak sasaran dilakukan seminggu setelah pelatihan untuk memantau perkembangan mereka apakah sudah mulai produksi serta kendala - kendala yang memerlukan solusi.

\section{Uji fisik produk}

Uji sifat fisik terhadap body cream dan body lotion meliputi:

1. Uji organoleptik yaitu pengamatan secara langsung terhadap produk meliputi warna, bau/aroma, tekstur dan bentuk.

2. Uji $\mathrm{pH}$ dilakukan dengan menggunakan alat $\mathrm{pH}$ meter dengan cara mencelupkan ujung elektroda pada body cream dan body lotion kemudian $\mathrm{pH}$ dibaca.

3. Uji homogenitas dilakukan dengan dengan mengoleskan body creamdan body lotion diatas gelas obyek kemudian diamati ada tidaknya partikel kasar.

4. Uji viskositas dilakukan dengan menggunakan alat viscometer

\section{HASIL DAN PEMBAHASAN}

Body cream dan body lotion yang dihasilkan dalam pelatihan ini diberi logo dengan nama perusahaan "Magnolia" (Gambar 2). 

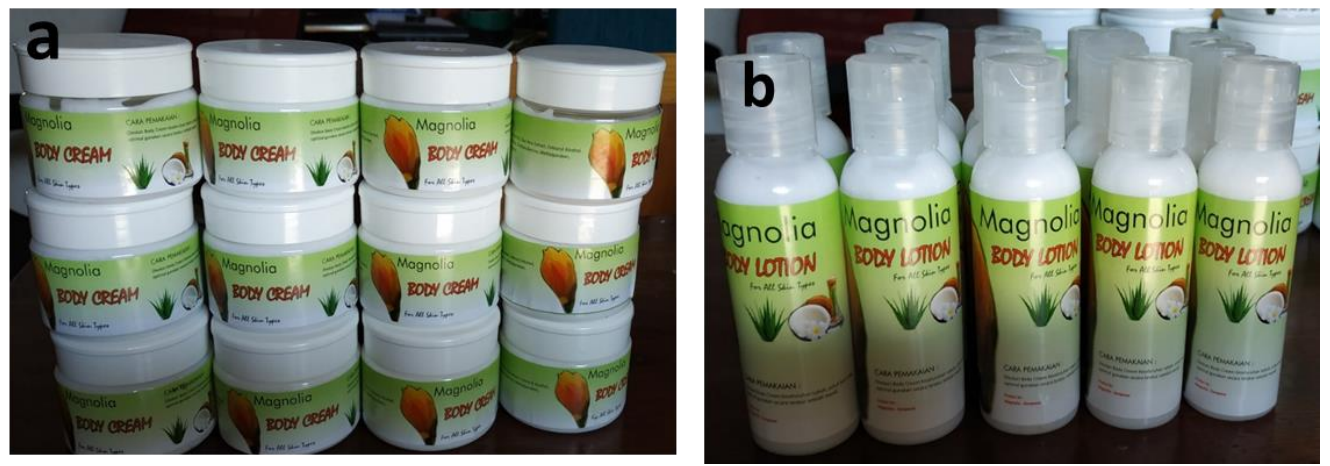

Gambar 2. Produk yang dihasilkan berupa a) body cream dan b) body lotion lidah buaya

Hasil uji organoleptik terhadap body cream dan lotion dicantumkan pada tabel 3.

Tabel 3. Hasil uji organoleptik body cream dan body lotion lidah buaya

\begin{tabular}{lll}
\hline Jenis uji & Body cream & Body lotion \\
\hline Warna & Putih susu & Putih susu \\
Bau/Aroma & Cendana & Melati \\
Tekstur & Lembut sangat kental & Lembut agak encer \\
Bentuk & cream & Lotion \\
\hline
\end{tabular}

Pada prinsipnya bahan - bahan yang digunakan dalam pembuatan body cream dan bod lotion lidah buaya adalah sama. Warna body cream adalah putih susu, bau/aroma cendana, tekstur lembut dan sangat kental dan berbentuk cream. Warna body lotion adalah putih susu, bau/aroma cempaka, tekstur lembut dan agak encer, bentuk lotion. Perbedaan body cream dan body lotion terletak pada teksturnya, dimana body cream lebih kental dari body lotion. Hal ini karena kandungan setil alkohol yang lebih banyak pada body cream. Setil alkohol berbentuk butiran berwarna putih, berbau khas lemak, rasa tawar dan melebur pada suhu $45-50^{\circ} \mathrm{C}$. Setil alkohol berfungsi sebagai pengemulsi, penstabil dan thickening agent. Thickening artinya pengental yang juga berfungsi mengikat fase air dan fase minyak yang terikat pada hidrofil lipofil balance (HBL).

Hasil uji fisik terhadap body cream dan body lotion meliputi $\mathrm{pH}$, homogenitas dan viskositas disajikan pada tabel 4 .

Tabel 4. Hasil uji fisik body cream dan body lotion lidah buaya

\begin{tabular}{lcc}
\hline Jenis uji & Body cream & Body lotion \\
\hline $\mathrm{pH}$ & 6,5 & 7,0 \\
Homogenitas & homogen & homogen \\
Viskositas & 95 Poise & 39 Poise \\
\hline
\end{tabular}

Hasil uji pH menunjukan bahwa body cream memiliki pH 6,5 dan body lotion memiliki pH 7,0. Kisaran $\mathrm{pH}$ kedua produk tersebut merupakan $\mathrm{pH}$ normal bagi kulit. Hasil uji homogenitas menunjukkan bahwa kedua produk bersifat homogen dimana tidak ditemukan butiran - butiran kasar pada produk, produk lembut dan halus bila diusapkan ke kulit. Hasil uji viskositas menunjukkan bahwa viskositas body cream adalah 95 Poise dan viskositas body lotion adalah 39 Poise. Viskositas ini berada pada kisaran viskositas menurut SNI 16-4339-1996 yaitu sebesar 20 500 Poise 


\section{KESIMPULAN}

1. Lidah buaya bisa diformulasikan menjadi body cream dan body lotion dengan konsentrasi 10 $20 \%$

2. Bodycream lidah buaya memiliki karakteristik: warna putih susu dengan aroma cendana, tekstur lembut, $\mathrm{pH}$ 6,5, viskositas 95 Poise dan homogen.

3. Body lotion lidah buaya memiliki karakteristik: warna putih susu dengan aroma melati, tekstur lembut, $\mathrm{pH}$ 7,0, viskositas 39 Poise dan homogen.

\section{UCAPAN TERIMAKASIH}

Penulis mengucapkan terimakasih kepada Lembaga Penelitian dan Pengabdian kepada Masyarakat (LPPM) Universitas Udayana atas bantuan dana pengabdian dengan skema Program Udayana Mengabdi tahun 2019. Terimakasih pula kepada mitra pengabdian Yayasan Puri Damai Ubud yang memfasilitasi acara pengabdian ini.

\section{DAFTAR PUSTAKA}

Hendrawati TY, Nugrahani RA, Utami S, Ramadhani AI (2017) Proses Bioindustri Berbahan Baku Tanaman Aloe vera (Aloe sinensis Baker). Samudra Biru, Yogyakarta.

Kumar, H.N.K., Chandana, E., Preethi, S.D., Chauhan, J.B. (2012). In vitro antimicrobial activity and phytochemical screening of Aloe vera Linn. Int J Curr Pharm Res 4(3): 45-47

Rahman AG, Astuti IY, Dhiani BA (2013) Formulasi lotion ekstrak rimpang bangle (zingiber purpureum roxb) dengan variasi konsentrasi trietanolamin sebagai emulgator dan uji iritasinya. Pharmacy 10(1): 41-54

Rusmarini IA dan Damai IW (2017) Taru Premana, Usadha dan Banten Bali Pulina.

Syamsiah SU, Priyantono, Suharyani I (2017) Formulasi Sediaan Gel dari Ekstrak Lidah Buaya, Daun Pandan dan Daun Sirih sebagai Anti Nyamuk. Jurnal Farmaku 1(1): 32-41

Usman Y (2018) Perbandingan uji stabilitas dan aktivitas gel lidah buaya (aloe vera 1.) pada basis Na. CMC dan Karbopol. Jurnal Ilmiah Kesehatan Diagnosis 12(6): 621-625 